\title{
ANALYSIS OF SACCHARIN IN RED PORRIDGE FROM TRADITIONAL MARKET WHICH VALIDATED USING UV- VISIBLE SPECTROPHOTOMETRIC
}

\author{
Crescentiana Emy Dhurhania ${ }^{1}$, Asri Nur Hidayah ${ }^{2}$ \\ ${ }^{1}$ Laboratorium Kimia Analisis, Program Studi DIII Farmasi, Sekolah Tinggi Ilmu Kesehatan Nasional, \\ Surakarta \\ 'Laboratorium Kimia Analisis, Program Studi DIII Farmasi, Sekolah Tinggi Ilmu Kesehatan Nasional, \\ Surakarta \\ Corresponding author : dhurhania@stikesnas.ac.id
}

\begin{abstract}
Saccharin is hundreds of times sweeter than sucrose, so that it can save production costs. Saccharin as a synthetic sweetener sugar substitute is very potential to be used in making sweet tasting foods that are sold at cheap prices in traditional market, one of which is red porridge. Many foods sold in traditional market are not accompanied by marketing permits as a home industry product, thus increasing the potential for saccharin abuse. This study aimed to determine the content of saccharin in red porridge sold in traditional market and to found out its suitability with the safe limits required in Regulation of the Head of the Food and Drug Supervisory Agency of the Republic Indonesia number 4 of 2014 concerning the maximum limit for the use of sweetener food additives. Identification of saccharin was carried out by resorcinol test and thin layer chromatography. Determination of saccharin was carried out by UV-Visible Spectrophotometric which had been validated at $267.5 \mathrm{~nm}$. The results show that 9 samples of red porridge sold in traditional market contain saccharin with concentrations of $0.0154-0.0652$ $\%$, so that it exceeds the required safe limit of $0.0100 \%$. In the analysis method validation, selective method is obtained in the range of $20-60 \mu \mathrm{g} / \mathrm{mL}$, with recovery $98.7371 \%$, coefficient of variation $0.8671 \%$, coefficient of correlation 0.9993 , limit of detection $1,9859 \mu \mathrm{g} / \mathrm{mL}$, limit of quantitation $6.6197 \mu \mathrm{g} / \mathrm{mL}$.
\end{abstract}

\section{Keywords :saccharin, red porridge, UV-Visible Spectrophotometric}

\section{Introduction}

Red porridge is a type of traditional food typical of Central Java which is often found in traditional market. Red porridge is made from flour and sugar which is processed using coconut milk until it becomes clay and sticky. Red porridge has sweet taste so it is always a favorite of children to adult. The use of sugar in large quantities is needed to produce sweet taste. Therefore, traders often use synthetic sweeteners because it has a sweetness level hundreds of time compared to sugar.

Red porridge sold in traditional markets are mostly made by small traders from local home industries who do not have a production permit from the local Health Office. As a result there is no control in the use of food additives such as synthetic sweeteners. Saccharin is an syntethic sugar substitute sweetener that is widely used, in addition to aspartame and cyclamate, especially by small traders and home industries because it has the highest sweetness level so it can save production costs. Saccharin 200 - 700 times sweeter than sucrose (Astuti, 2017), so it is very potential to be used in making sweet tasting foods that are sold at cheap prices in traditional market, one of which is red porridge. Many foods sold in traditional markets are not accompanied by marketing permits as a home industry products, thus increasing the potential for saccharin abuse.

In the results of the Food and Drug Supervisory Agency testing in 2011 on products circulating in the community, it was known that out of 3,925 samples found 52 samples containing saccharin exceeded the requirements limit (BPOM, 2012). In the Juadah market in Pontianak, it was found that out of 26 samples of non hygienic snacks, 3 of them contained synthetic sweeteners that exceeded the limit (BPOM, 2012). Traditional snacks at the 
Belimbing market in Malang which were taken 6 samples, proved that 4 samples contained saccharin and 1 of them exceeded the maximum limit (Rini, 2013).

The amount of saccharin abuse potential that exceeds the maximum limit in red porridge which is sold in traditional markets has never been studied. This study aimed to determine the content of saccharin in red porridge sold in traditional market and to found out its suitability with the safe limits required in Regulation of the Head of the Food and Drug Supervisory Agency of the Republic Indonesia number 4 of 2014 concerning the maximum limit for the use of sweetener food additives.

\section{Methods}

\section{Equipment}

A set of UV-Vis Spectrophotometers (UV mini-1240 Shimadzu, Japan), analytical balance (Ohaus EP214 with weighing sensitivity 0.0001 gram), dan a set of glassware (Pyrex).

\section{Material}

Red porridge samples were obtained from 3 traders in Jambangan Market, Mojogedang, Karanganyar. Saccharin (Merck Millipore), ethanol (Merck), ethyl acetate (Merck), ether (Merck), resorcinol (Merck), $\mathrm{NaOH}$ (Merck), $\mathrm{H}_{2} \mathrm{SO}_{4}$ (Merck), $\mathrm{NH}_{4} \mathrm{OH}$ (Merck), silica gel $60 \mathrm{GF}_{254}$ (Merck), $\alpha$ naphthylamine (Merck Millipore), anhydrous $\mathrm{Na}_{2} \mathrm{SO}_{4}$ (Pudak), Aquadest (Bratachem).

\section{Methods}

1. Positive control preparation

Positive control was in the form of red porridge that was intentionally made by adding $100.0 \mathrm{mg}$ of saccharin to a brown sugar solution, which was cooked with rice flour and coconut milk, while stirring constantly to produce $1000 \mathrm{~g}$ red porridge.

2. Identification of saccharin

a. Resorcinol test

The $10 \mathrm{~g}$ sample was acidified with $10 \%$ $\mathrm{H}_{2} \mathrm{SO}_{4}$ then extracted with $25 \mathrm{~mL}$ ether. The ether extract was washed twice each with $10 \mathrm{~mL}$ of $5 \% \quad \mathrm{NH}_{4} \mathrm{OH}$, then separated. Amonium hidroksida layer was added with $10 \mathrm{~mL} \mathrm{25 \%}$ $\mathrm{HCl}$, then extracted 3 times each with $25 \mathrm{~mL}$ ether. The ether phase was evaporated in open air, then added 15 drops of concentrated $\mathrm{H}_{2} \mathrm{SO}_{4}$, transferred to a test tube and added $40 \mathrm{mg}$ of resorcinol. The solution was heated slowly over low heat until it turns into dirty green. After cold, the solution was added with $2 \mathrm{~mL}$ of aquadest and $10 \% \mathrm{NaOH}$ excessively. Detection was done under $\mathrm{UV}_{254}$ (Rohman and Sumantri, 2007). The same thing was done to the positive control.

b. Thin layer chromatography

The $10 \mathrm{~g}$ sample was acidified with $10 \%$ $\mathrm{H}_{2} \mathrm{SO}_{4}$ then extracted with $50 \mathrm{~mL}$ ethyl acetate. The ethyl ecetate phase was filtered through anhydrous $\mathrm{Na}_{2} \mathrm{SO}_{4}$ then evaporated to remaining $2 \mathrm{~mL}$. The sample solution and the standard solution of saccharin in 50\% ethanol each of $1,5 \mu \mathrm{L}$ were dropped on the stationary phase of silica gel $60 \mathrm{GF}_{254}$. Elution was carried out by ehanol_ammonia $(9: 1)$ as a mobile phase. Spot detection was done under $\mathrm{UV}_{254}$. (Rohman and Sumantri, 2007). The same thing was done to the positive control.

3. Standard solution preparation

A number of saccharin were dissolved in aquadest to obtain $1000 \mu \mathrm{g} / \mathrm{mL}$ standard stock solution. A number of volumes from standard stock solution were diluted to obtain the appropriate concentrations of standard solution needed at each step of the analysis.

4. Maximum wavelength

Absorbance of $40 \mu \mathrm{g} / \mathrm{mL}$ standard solution was measured at wavelengths of 240$280 \mathrm{~nm}$. The maximum wavelength was determined from the spectrogram obtained.

5. Calibration curve

The absorbance of $20-60 \mu \mathrm{g} / \mathrm{mL}$ standard solution was measured at the maximum wavelength. The relationship curve between concentrations and absorbance was used to obtain the linear regression equation to obtain coefficient of correlation ( $r$ ).

6 . Range and linearity

The range was obtained from the series of standard solution concentrations which show that the analytical method is capable of producing accuracy, precision and linearity that meets the requirements.Linearity was defined in the range of analytical methods determined by the coefficient of correlation.

7. Accuracy

Accuracy was obtained by standard addition method. The absorbance of the solution prepared from the positive control was measured at the maximum wavelength. Accuracy was expressed by the recovery of the amount of saccharin which added to red porridge in positive control.

8. Precision

Precision was expressed by the coefficient of variation from the results of the 
repeated determination of the homogeneous sample.

9. Selectivity

Selectivity was expressed by achieving the accuracy of the analytical methods that meets the requirements.

10. Sensitivity

Sensitivity was expressed by the detection limit with a 3:1 signal-to-noise ratio and quantitation limit with a 10:1 signal-to-noise ratio.

\section{Determination of saccharin}

The $10 \mathrm{~g}$ sample was dissolved with aquadest then extracted three times each with 20 $\mathrm{mL}$ chloroform. The aquadest phase was collected then filtered and diluted to obtained $100.0 \mathrm{~mL}$ test solution (Rohman and Sumantri, 2007). The absorbance of test solution was measured at the maximum wavelength. The same thing was done to the positive control.

\section{Analysis}

Analysis of saccharin identification results in resorcinol test was carried out by comparing the green fluorescence produced by the sample to positive control.Analysis of saccharin identification results in thin layer chromatography test was carried out by comparing the color, shape, and HRf value produced by the sample to positive control and standard solution.Quantitative analysis was performed using a regression equation that produced a calibration curve.

\section{Results and Discussion}

\section{Saccharin identification}

The resorcinol test for all samples and positive control produce a phosphorescence green color as presented on Figure 1. It shows that all samples contain saccharin.

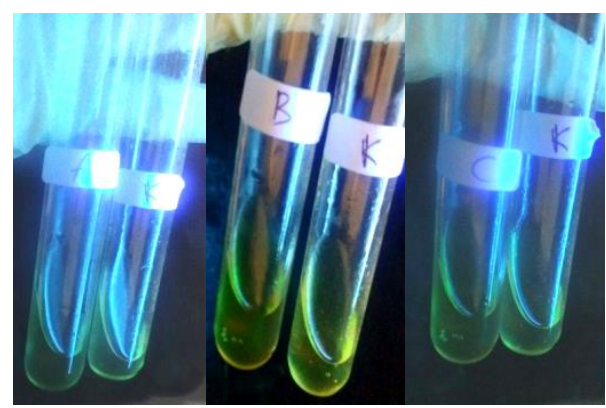

Figure 1. The resorcinol test results under $\mathrm{UV}_{254}$ on samples from traders $\mathrm{A}, \mathrm{B}, \mathrm{C}$, with $\mathrm{K}$ positive control as a comparison

Saccharin identification by Thin Layer Chromatography with $\mathrm{UV}_{254}$ detection provides the specificity of analysis results, which is shown with the reduction of plate phosphorescence, in the form of purple spots as presented on Figure 2, with HRf values presented in table 1. Based on the similarity of the spot profile and HRf value between the sample, positive control, and comparative standard solution of saccharin, it can be concluded that all samples contain saccharin.

Table 1. Thin Layer Chromatography results under $\mathrm{UV}_{254}$ on samples from traders A, B, C, with K

\begin{tabular}{ccc} 
positive control and S standard as a comparison \\
\hline Preparation & HRf & Spot profile \\
\hline sample form trader A & 75 & Purple, Ovale \\
sample form trader B & 78 & Purple, Ovale \\
sample form trader C & 77 & Purple, Ovale \\
positive control K & 80 & Purple, Ovale \\
saccharin standard S & 78 & Purple, Ovale \\
\hline
\end{tabular}




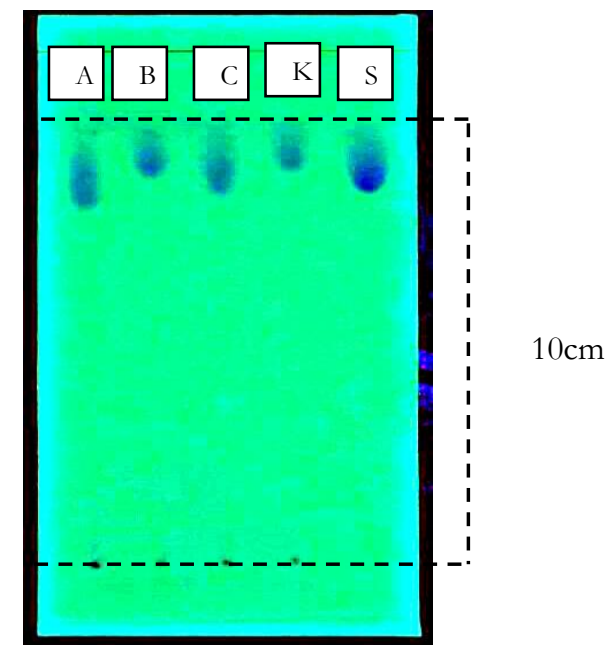

Figure 2. Thin Layer Chromatography results under $\mathrm{UV}_{254}$ on samples from traders $\mathrm{A}, \mathrm{B}, \mathrm{C}$, with $\mathrm{K}$ positive control and S standard as a comparison

\section{Maximum wavelength}

The $40 \mu \mathrm{g} / \mathrm{mL}$ standard solution scanned at 240-280 nm produces the highest absorbance at $267.5 \mathrm{~nm}$. The maximum wavelength obtained is similar to the visualization of the physical method at a maximum wavelength of $266 \mathrm{~nm}$ according to Rohman and Sumantri (2007).

\section{Validation of the analysis method}

Validation of the analysis method aims to ensure that the analytical method used is capable of producing valid data.Saccharin analysis method used in this study is simpler than saccharin analysis methods that have been used before (Mairizki 2014) and implemented on a sample matrix that is different from previous similar studies (Fajari, 2014; Mairizki 2014). Therefore, before being implemented on the red porridge sample, it was necessary to validate the analysis method.Validation of the analysis method used in this study includes testing of several parameters, covering accuracy, precision, linearity, sensitivity, and selectivity in the range that becomes the work area. The results obtained in the validation of the analysis method are explained as follows:

1. Range and linearity

Range ensure the series of standard solution concentrations that is able to produce accuracy, precision and linearity that meet the requirements. Linearity ensure the relationship between saccharin concentrations and absorbance, which was carried out by determining the linear calibration curve in the range of analysis methods that become the work area. Based on the results obtained it is known that between saccharin concentrations and absorbance has a good linear relationship in the range of $20-60 \mu \mathrm{g} / \mathrm{mL}$. This good linearity is indicated by the value of the coefficient of correlation (r) of 0.9993 which is produced by the linear regression equation of the linear calibration curve on figure 3. The coefficient of correlation obtained has met the linearity requirement of $>0.9970$ (Riyanto, 2014), even the value is closer to 1 than the linearity test results on the validation of saccharin analysis method by spectrophotometry in branded sweeteners to wit 0.9988 in the range of 31,20182-122,24886 $\mu \mathrm{g} / \mathrm{mL} \quad$ (Fajari, 2014) 
Abs

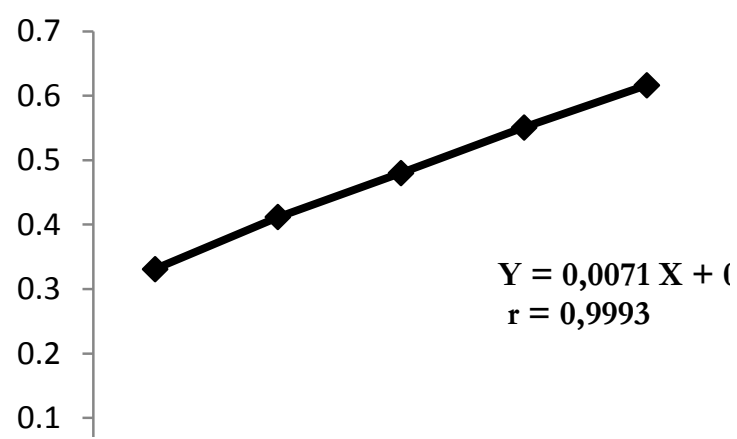

Figure 3. Saccharin linear calibration curve

\section{Accuracy}

Accuracy ensure the closeness between the measured and the real concentrations of the analytes which are expressed as recovery. Accuracy was determined by the addition standard method because the real saccharin content in samples were unknown. Recovery is obtained at $98,7371 \%$ so that the analysis method has good accuracybecause it meets the recovery requirements for analytes with a content of not more than $100 \mu \mathrm{g} / \mathrm{mL}$ and not less than $10 \mu \mathrm{g} / \mathrm{mL}$, which is 90-107 \% (Riyanto, 2014). The accuracy obtained in this study is almost the same as the accuracy obtained on the validation of saccharin analysis method by spectrophotometry in branded sweeteners to wit $100.06 \%$ (Fajari, 2014), even better than recovery of saccharin determination in soft drinks by High Performance Liquid Chromatography to wit $94.9 \%$ (Mairizki 2014).

\section{Precision}

Precision ensure the suitability between a series of measurements from a homogeneous sample which are expressed as coefficient of variation. In this study coefficient of variation is obtained at $0,8671 \%$ so the analytical method has very good precision because it meets the requirements of the coefficient of variation for analytes at parts per million level, which is not more than 20\% (Riyanto, 2014). The precision obtained in this study is similar with the precision obtained on the validation of saccharin analysis method by spectrophotometry in branded sweeteners to wit $0.88273 \%$ (Fajari, 2014).

\section{Selectivity}

Selectivity describes the ability of an analytical method to accurately measure the response of an analyte in the presence of other components that may be present in the sample.Therefore selectivity is expressed by achieving the accuracy of the analytical method that meets the requirements.Based on the recovery obtained, the analytical method used has good accuracy and meets the requirements. Thus the analytical method used can be concluded selectivebecause it is able to accurately measure the response of the analyte in the presence of other components that may be in the sample.

\section{Sensitivity}

Sensitivity analysis methods describe the sensitivity of analytical methods to measure the the smallest level of analytes.Sensitivity is expressed by detection limit and quantitation limit. Detection limits were calculated to determine the smallest levels of analytes that can still be detected, while the quantitation limit ensures the smallest level of analyte that was able to meet the requirements of accuracy and precision.In this study the determination of detection limit and quantitation limit was based on the slope of linear calibration curveand the standard deviation of blank response which were calculated using the linear regression equation.Detection limits and quantitation limits obtained are $1.9859 \mu \mathrm{g} / \mathrm{mL}$ and $6.6197 \mu \mathrm{g} / \mathrm{mL}$, respectively.This shows that the analytical method used in this study is able to provide more sensitive results, with a detection limit and a quantitation limit that is less than the detection limit and quantitation limit on the validation of saccharin analysis method by spectrophotometry in branded sweeteners to wit $2,67 \mu \mathrm{g} / \mathrm{mL}$ and $8.89 \mu \mathrm{g} / \mathrm{mL}$, respectively (Fajari, 2014). 


\section{Determination of Saccharin}

The results show that 9 samples of red porridge from 3 traders in traditional market contain saccharin with concentrations of 0.0154 $0.0652 \%$, so that exceeds the safe limit of $0.0100 \%$ required in Regulation of the Head of the Food and Drug Supervisory Agency of the Republic Indonesia number 4 of 2014.

\section{Conclusion}

The results show that 9 samples of red porridge sold in traditional market contain saccharin with concentrations of 0.0154-0.0652 $\%$, so that exceeds the required safe limit of $0.0100 \%$. In the analysis method validation, selective method is obtained in the range of 20$60 \mu \mathrm{g} / \mathrm{mL}$, with recovery $98.7371 \%$, coefficient of variation $0.8671 \%$, coefficient of correlation 0.9993 , limit of detection $1,9859 \mu \mathrm{g} / \mathrm{mL}$, limit of quantitation $6.6197 \mu \mathrm{g} / \mathrm{mL}$.

\section{References}

Astuti, E.J., 2017, Penggunaan Sakarin sebagai Pemanis Sintesis dalam Makanan dan Minuman. In Proceeding of Rapat Kerja Fakultas Ilmu Kesehatan: Peningkatan keilmuan Solusi Tantangan Profesi Kesehatan. Universitas Muhammadiyah Malang. Malang. 101-105.

Badan Pengawas Obat dan Makanan Republik Indonesia. 2012. Laporan Tahunan 2011. Badan Pengawas Obat dan Makanan Republik Indonesia.94-96.
Badan Pengawas Obat dan Makanan Republik Indonesia. 2014. Batas Maksimum Penggunaan Bahan Tambahan Pangan Pemanis. Balai Pengawas Obat dan Makanan. Jakarta.

Fajar, D.N., 2014. Validasi Metode Analisis Kadar Sakarin secara Spektrofotometri.Skripsi.Fakultas Matematika dan Ilmu Pengetahuan Alam, Jurusan Pendidikan Kimia.Universitas Negeri Yogyakarta. Yogyakarta

Rini, S.D.P., 2013. Analisis Kuantitatif Sakarin sebagai Pemanis Sintesis dalam Jajanan Tradisional dengan Metode KLTDensitometri.Universitas Muhammadiyah Malang. Malang.

Riyanto, 2014. Validasi \& Verifikasi Metode Uji: sesuai dengan ISO/IEC 17025 Laboratorium Pengujian dan Kalibrasi, Ed. 1. Cet. 1.Deepublish.Yogyakarta.3456.

Rohman, A. and Sumantri. 2007. Analisis Makanan. Universitas Gajah Mada Press. Yogyakarta.

Mairizki, F., 2014. Penentuan Natrium Sakarin, Asam Benzoat, dan Kafein Menggunakan Kromatografi Cair Kinerja Tinggi Fase Terbalik. Jurnal RAT, Vol. 3. No. 2. 463-471 